\title{
HUMAN RIGHTS UNDER THE ETHIOPIAN CONSTITUTION: A DESCRIPTIVE OVERVIEW
}

Adem Kassie Abebe *

\begin{abstract}
This article summarizes human rights under the Ethiopian Constitution (mainly surrounding Chapter 3 of Constitution and related constitutional provisions on human and democratic rights), and forwards some insights. It, inter alia, covers various aspects of the application and interpretation of human rights provisions, limitation and derogation from protected rights, the amendment procedure and constitutional adjudicatory jurisdiction. The relevance attached to international and regional human rights instruments and their status in the Ethiopian hierarchy of laws is noted. Although there are some references to factual situations, the article primarily considers the constitutional landscape. The article thus attempts to cover a wider spectrum of issues, and its purpose is not to discuss each issue in detail, but to forward an overview and offer some insights.
\end{abstract}

\section{Key words:}

Human rights, The Ethiopian Constitution, Ethiopia, constitutional adjudication, constitutional amendment, constitutional remedies.

\section{Introduction}

Ethiopia had three written constitutions (in 1931, 1955 and 1987) before the 1995 FDRE Constitution. The 1931 Constitution $^{1}$ does not have significant relevance for the human rights discourse as it was primarily designed to reaffirm and fortify the absolute power of Emperor Haile Selassie I. ${ }^{2}$ The state was generally not understood to owe duties to its subjects. ${ }^{3}$ The 1955 Constitution ${ }^{4}$

* LLB (Jimma University); LLM: Centre for Human Rights, University of Pretoria; Doctor of Laws Candidate, Researcher and Tutor, Centre for Human Rights, Faculty of Law, University of Pretoria..

${ }^{1}$ Constitution of Ethiopia, (adopted in July 1931). The absence of written constitutions before 1931 does not however mean that there were no (unwritten) constitutions.

2 For more discussion see, Fasil Nahum (1997), A Constitution for a Nation of Nations: The Ethiopian Prospect (Red Sea Press) at 21 (See generally Chapter 2).

3 T Regassa (2009) "Making Legal Sense of Human Rights: The Judicial Role in Protecting Human Rights in Ethiopia", 3(2) Mizan Law Review 287, at 297; see also CN Paul \& C Clapham (1972), Ethiopian Constitutional Development: A Sourcebook, Addis Abeba University Press) 
was adopted in response to the inadequacy of the 1931 Constitution to accommodate the more complex legal and political scenario at domestic and international levels. Although this Constitution recognized a handful of rights, their relevance was vastly compromised due to the absolute power of the Emperor, and the absence of an organ empowered to interpret and apply the Constitution. ${ }^{5}$ Besides, most of the rights were entangled with claw-back clauses. $^{6}$

The military junta (which called itself the Dergue, which literally means Committee) took power after dethroning Emperor Haile Selassie I in 1974, and it adopted a Constitution in 1987 after 13 years of constitutional lacuna. The 1987 Constitution ${ }^{7}$ highly accentuates economic, social and cultural rights due mainly to the socialist tendency of the regime. It was nonetheless a regime beset by fear and there was no fertile ground to foster the recognition and exercise of human rights. ${ }^{8}$

The current Ethiopian Constitution entered into force on 21 August 1995. ${ }^{9}$ In a stark break from its predecessors, the FDRE Constitution establishes an ethnic based federal state consisting of regional states delineated on the basis of settlement patterns, language, identity, and consent of the people concerned. ${ }^{10}$ The Constitution also represents a major breakthrough in terms of human rights. It was crafted to respond to the underlying causes that triggered the widespread

${ }^{4}$ Revised Constitution of the Empire of Ethiopia, Proclamation No. 149 of 1955.

${ }^{5}$ See generally G Krzeczunowicz (1984), 'Hierarchy of laws' 1(1) Journal of Ethiopian Law, 11

${ }^{6}$ T Regassa, supra note 3 above, at 298.

${ }^{7}$ Constitution of the People's Democratic Republic of Ethiopia, adopted 22 February 1987.

${ }^{8}$ In addition to the four Constitutions alluded to, Ethiopia also had the 1991 Transitional Period Charter of Ethiopia which organized the Transitional Government between 22 July 1991 and 21 August 1995. This Charter recognized 'freedom, equal rights and self-determination of all the peoples' as its governing principles.

${ }^{9}$ There is no indication that the Constitution or any of its elements were inspired by constitutions in other parts of the world. Nonetheless, the human rights provisions of the Constitution must have been highly influenced by the development internationally.

${ }^{10}$ See FDRE Constitution arts 1, 46 and 47. Currently, there are nine regional states and two city states under federal administration, Addis Abeba and Dire Dawa. Each level of government, Federal and Regional, has its own legislative, executive and judicial structures. The judicial structure is composed of first instance, high court and supreme courts at the federal level and in each regional state. 
conflict and the ultimate downfall of the Dergue military junta in 1991. It addresses the volatile issues of ethnicity and self-determination. ${ }^{11}$

It is with this mindset that the drafters of the Constitution articulated the common objective of "building a political community founded on the rule of law and capable of ensuring a lasting peace guaranteeing a democratic order". ${ }^{12}$ Unlike its predecessor which vehemently promoted a unitary system, the current Constitution emphasizes, tolerates and even encourages diversity and attempts to address it through an ethnic-based federal system. The relevance accorded to human rights is reflected from the outset by the preamble of the FDRE Constitution which emphatically affirms "the full respect for individual and people's fundamental rights" as a condition precedent and foundational principles for the success of this sparkling ambition. ${ }^{13}$

The article presents an overview of the peculiar features and application of the Ethiopian Constitution regarding human rights and briefly discusses issues of interpretation. Moreover, the rights guaranteed by the Constitution are highlighted followed by a brief discussion on restrictions, derogation during emergencies, amendment, adjudication and constitutional remedies.

\section{Peculiar features and application of the Constitution (regarding human rights and freedoms)}

The Constitution devotes more than one third of its content to provisions on fundamental human and people's rights. ${ }^{14}$ Moreover, there are provisions that deal with national policy principles and objectives which either establish important guarantees or have direct relevance to the interpretation of fundamental rights. The Constitution imposes a responsibility and duty to the respect and enforcement of fundamental rights and freedoms at all levels of the federal and state legislative, executive and judicial bodies. ${ }^{15}$

The Constitution further elevates the horizon of human rights through reference to international and regional human rights instruments as thresholds

${ }^{11}$ See the preamble which starts, 'We the nations, nationalities and peoples of Ethiopia'. The Constitution serves as an expression of sovereignty which resides in nations, nationalities and peoples of Ethiopia (FDRE Constitution Art. 8).

${ }^{12}$ FDRE Constitution, preamble, para 1.

${ }^{13}$ FDRE Constitution, preamble, para $2 \& 5$.

${ }^{14}$ See FDRE Constitution, Chapter 3, Arts. $13-44$.

${ }^{15}$ See FDRE Constitution, Art. 13(1) - this reinforces the supremacy of the Constitution and the general responsibility and duty the Constitution imposes on "all citizens, organs of state, political organizations, other associations as well as their officials" to obey and ensure its observance (Arts 9(1) and (2)). 
for the interpretation of its human rights provisions. ${ }^{16}$ Another prominent feature is the implicit recognition of the independence, interrelatedness and indivisibility of all generations of human rights by incorporating them on equal footing without any difference in consequence. ${ }^{17}$

In terms of substantive guarantees, the Ethiopian Constitution is the only one in Africa to recognize the right to self-determination of "nations, nationalities and peoples". ${ }^{18}$ This right extends up to creating regional states within the federal state and can even extend up to secession under the conditions stated in the Constitution. However, the exercise of the right to secession has not so far been seriously considered by any of the regions although a demand for secession has been espoused by some rebel groups. ${ }^{19}$

The Constitution also establishes separate procedures for the amendment of the human rights and fundamental freedoms. ${ }^{20}$ To avoid any possible regression and safeguard the gains, a more stringent and rigorous procedure is required to amend the provisions relating to the fundamental rights and freedoms than the remaining parts of the Constitution. ${ }^{21}$ The Constitution fortifies these features through the supremacy clause under Article 9(1).

Application relates to who is bound to comply with the obligations that rights create. It helps to determine who may stand to be guilty of violating human rights. At a macro level, constitutions generally regulate the relationship between the state and its subjects, and amongst the state institutions themselves (vertical application). At a micro level, fundamental rights and freedoms delimit

${ }^{16}$ See FDRE Constitution, Art. 13(2).

${ }^{17}$ This is in conformity with the 1993 Vienna World Conference on Human Rights (para 5), and the African Charter on Human and Peoples' Rights which affirms indivisibility of all kinds of rights in the preamble (adopted 27 June 1981, Preamble Para 6). For a detailed discussion see H Steiner \& P Aliston International Human Rights in Context: Law Politics, and Morals ( $2^{\text {nd }}$ ed, 2000, Oxford University Press). The three generation of rights are first generation civil and political rights, second generation economic, social and cultural rights, and third generation group rights.

18 See also C Heyns and W Kagoungo (2006), 'Constitutional human rights law in Africa' (22) South African Journal of Human Rights 673, at 678. See FDRE Constitution, Art. 39(1).

${ }^{19}$ The Oromo Liberation Front and the Ogaden National Liberation Front are examples in this regard. There is better tolerance for internal self-determination: for instance, the Silte exercised their right to internal self determination.

${ }^{20}$ For the procedures of amendment see FDRE Constitution, Arts. 105(1) and (2).

${ }^{21}$ For a detailed discussion of the safeguards and procedure of amendment see item $(\mathrm{G})$ below. 
relationships between and among subjects themselves (horizontal application). ${ }^{22}$ Most constitutions often anticipate and predominantly consider and regulate the vertical application of rights. Some progressive constitutions however also have desirously acknowledged horizontal application of human rights. ${ }^{23}$

In the Ethiopian Constitution, the Chapter that deals with human rights only explicitly recognizes their vertical application. ${ }^{24}$ The absence of mention of other entities in the same Chapter that deal with human and fundamental rights has led some to conclude that the Constitution is one of a handful of African constitutions that contain application clauses but do not recognize horizontal application of rights. ${ }^{25}$

A holistic and purposive view at the Constitution, however, reveals that even individuals and juristic persons are bound by the bill of rights. This is because the Constitution enjoins, though not exclusively concerning the bill of rights, "all citizens, organs of state, political organizations, other associations as well as

${ }^{22}$ For a discussion of the vertical and horizontal application of rights and the theoretical and philosophical concepts that underlie horizontal application see generally DM Chirwa 'In search of philosophical justifications and suitable models for the horizontal application of human rights' 2008 8/2 African Human Rights Law Journal 294; and JJ Paust 'Human rights responsibilities of private corporations' (2002) 35 Vanderbilt Journal of Transnational Law 801

${ }^{23}$ The Constitution of the Republic of South Africa (Act No 108 of 1996) provides an interesting example. Section 8(2) provides 'A provision of the Bill of Rights binds a natural or juristic person if, and to the extent that it is applicable, taking into account the nature of the right and the nature of any duty imposed by the right'. This is a very broad and obscure standard which obviously necessitates a case by case and individualized consideration of each situation on its own facts - it is hardly possible to develop a general all-encompassing standard. The Constitutional Court of South Africa in one case referred to the 'intensity of the right', which itself is unclear and barely elaborative, as a determining factor - Case of Khumalo v Holomisa 2002 (5) SA 401(CC). See also South African Institute for Advanced Constitutional, Public, Human Rights and International Law (SAIFAC) 'Business and Human Rights: The responsibilities of corporations for the protection and promotion of human rights' (2008). For a discussion of the application of the bill of rights in the South African Constitution see I Currie \& Johan de Waal The bill of rights handbook (5th ed, 2005, Juta Publication) 30-78.

${ }^{24}$ See FDRE Constitution, Art. 13(1) which imposes a duty to respect and enforce only on 'All federal and state legislative, executive and judicial bodies'.

25 The other two are Burundi and Cape Verde. A total of 13 constitutions of African countries contain application provisions. See Heyns \& Kagoungo "Constitutional Human Rights Law in Africa" supra note 18 above. 
their officials" to obey and ensure its observance. ${ }^{26}$ This clearly exacts compliance and imposes a duty on the listed persons and entities to obey and observe, inter alia, the fundamental human rights and freedoms stipulated under the Constitution.

\section{Interpretation of Human Rights and Fundamental Freedoms}

Interpretation refers to the ascertaining or determination of the meaning of a legal provision. ${ }^{27}$ Contemporary constitutions generally provide that their bill of rights should be interpreted generously and holistically. ${ }^{28}$ The Ethiopian Constitution does not include a general interpretation clause whose application permeates all of its provisions. It does however contain a laudable interpretation clause regarding the chapter dealing with human rights and fundamental freedoms. ${ }^{29}$ Article 13(2) requires that the bill of rights "shall be interpreted in a manner conforming to the principles of the Universal Declaration of Human Rights (UDHR), International Covenants on Human Rights ${ }^{30}$ and international

${ }^{26}$ See FDRE Constitution, Article 9(2). Note that the list does not include NonEthiopians as well as juristic persons established under the laws of other states. Considering the effects of globalization and the ever increasing presence of foreigners and the increasing role of foreign companies in the Ethiopian economy, an amendment may be necessary.

27 The power of interpreting the Constitution lies with the House of Federation, a political organ with semi-legislative power consisting of representatives of nations, nationalities and peoples of Ethiopia. Each nation, nationality and people has at least one representative and one more for each one million of its population. See arts 6166 of the FDRE Constitution.

${ }^{28}$ See for instance Section 39 of the Constitution of South Africa. This provision further requires that the promotion of values that underlie open and democratic societies should guide the interpretation of the bill of rights. The Constitutional Court of South Africa has consistently reiterated this on several occasions; see for instance $S v$ Makwanyane 1995 (3) SA 391 (CC), and S v Mhlungu 1995 (3) SA 391 (CC). More importantly, Art. 4 of the International Covenant on Civil and Political Rights (ICCPR, adopted 16 December 1966 and entered into force 23 March 1976) and Art. 5 of the International Covenant on Economic, Social and Cultural Rights (ICESCR, Adopted by the UN General Assembly on 16 December 1966 and entered into force 3 January 1976) note that the provisions therein should not be interpreted to undermine other provisions or in a way that limits rights more than anticipated and permitted.

${ }^{29}$ See FDRE Constitution, Art. 13(2).

${ }^{30}$ Apparently, this seems to refer to the 1966 Covenants (ICCPR and ICESCR) which, together with the Universal Declaration of Human Rights (UDHR, adopted 10 December 1948) form the International Bill of Rights. The FDRE Constitution does not however succinctly determine the status of ratified international instruments in the Ethiopian hierarchy of laws. For more discussion on this, see I. Idris 'The place of 
instruments adopted by Ethiopia". ${ }^{31}$ It should be noted that the relevant instruments need not have been ratified by Ethiopia. However, the reference is limited to adopted instruments and does not include customary international law per se. ${ }^{32}$

The status of international instruments in general (and human rights instruments in particular) in the Constitution is not definite and is subject to academic debate. Article 9(1) of the Ethiopian Constitution declares the supremacy of the Constitution. Hence, a literal reading of this provision clearly indicates that international instruments, which, under Article 9(4), are made an integral part of the laws of the land upon ratification, are subordinate to the Constitution. Since human rights treaties are also part of a special kind of international agreements, they should be understood to be subordinate to the Constitution. However, the inclusion of the interpretation clause (Article 13/2 in relation to the fundamental rights chapter) has led some scholars to conclude that international human rights instruments adopted (and not just ratified) have a status higher than, or at least equal to, Chapter 3 of Constitution itself. ${ }^{33}$

International Human Rights Conventions in the 1994 Federal Democratic Republic of Ethiopia Constitution' (2000) 20 Journal of Ethiopian Law 113; and SA Yeshaneh 'The justiciability of human rights in the Federal Democratic Republic of Ethiopia' (2008) 8/2 African Human Rights Law Journal 273.

31 'International instruments' should be understood to include regional and sub-regional instruments as well. If the words 'international instruments' were not meant to include regional instruments, the reference to 'International Covenants on Human Rights' would have sufficed. The Constitution could have explicitly mentioned the African Charter on Human and Peoples' Rights especially as the African Charter (Article 21) is the only human rights instrument that unequivocally establishes the right to self-determination of peoples, which underpins the very foundation of the Ethiopian Constitution. For the application of this interpretation clause see $\mathrm{Dr}$ Negaso Gidada $v$ the House of Peoples' Representatives and the House of Federation, Federal High Court, Appeal, Addis Ababa, Judgment 4 January 2006 which applied the UDHR (even though the Supreme Court rejected the ruling of this Court); and Miss Tsedale Demissie v Mr Kifle Demissie, Federal Supreme Court Cassation Division, File 23632, Judgment 6 November 2007 which applied Convention on the Rights of the Child (adopted 20 November 1989).

${ }^{32}$ Similarly, Art 9(4) of the FDRE Constitution, which makes ratified instruments part of the law of the land, does not mention customary international law. Note that Article 9 is the interpretation provision whereas Article 13(1) is the incorporation provision.

33 Ibrahim Idris (2000) 'The place of International Human Rights Conventions in the 1994 Federal Democratic Republic of Ethiopia Constitution', 20 Journal of Ethiopian Law 113. 
Nevertheless, the Constitution only requires reference to the 'principles' such as principles of universality, indivisibility and interdependency of all human rights, the duty to respect, to protect, to fulfill, and the principle that limitations of rights are the exceptions etc, rather than the provisions of international instruments which outline the specific rights to guide the interpretation of the provisions in the fundamental rights chapter. It also broadly refers to hard as well as soft instruments. Most importantly, conformity is required only when there is the need for interpretation which excludes cases where clear differences exist between the Constitution and international instruments as well as cases of clear constitutional provisions which merely require application of the Constitution. As such, even international human rights instruments have a status subordinate to the Constitution.

The requirement that interpretations should conform to international instruments, however, only applies to human rights provisions included in Chapter 3 of the Constitution. ${ }^{34}$ There are other provisions outside this Chapter that are directly or indirectly relevant to human rights. Chapter 10 that deals with the National Policy Principles and Objectives, for instance, contains essential provisions germane to human rights particularly to socio-economic and environmental rights. ${ }^{35}$ Even more directly relevant is the provision that deals with derogation of rights. ${ }^{36}$ Interpreting the derogation clause probably needs more guidance based on international and regional instruments and jurisprudence. However, since the provision dealing with the substantive and procedural requirements for derogation of rights in emergency exists outside Chapter 3, the interpretation of the derogation provision does not have to be in conformity with international standards. ${ }^{37}$ However, the interpretation provision should be understood purposively to oblige guidance and conformity in interpreting all provisions that have direct or indirect bearing on the fundamental rights and freedoms enshrined in the Constitution.

The Constitution does not say anything about the relevance of foreign law and jurisprudence. However, Proclamation No. 251/2001 which was enacted to consolidate the House of Federation (HoF), i.e., the organ which has the power to interpret the Constitution, authorizes the HoF to identify, develop and

${ }^{34}$ See Art. 13(2) of FDRE Constitution 'the fundamental rights and freedoms specified in this Chapter' (emphasis added).

35 See FDRE Constitution, Arts. 88-92 dealing with political, economic, social and environmental objectives, and principles of foreign policy.

${ }^{36}$ See FDRE Constitution, Art 93.

${ }^{37}$ There are however several rights which are non-derogable under international human rights law but are derogable under the Ethiopian Constitution - for instance, the right to life. For further discussion on derogation of rights, see item (f) below. 
implement principles of constitutional interpretation as it deems appropriate. ${ }^{38}$ The legislation enacted to establish the Council of Constitutional Inquiry ${ }^{39}$ reiterates the same authorization. ${ }^{40}$ This allows the HoF to look into foreign law and comparative jurisprudence in consolidating its own principles of interpretation. ${ }^{41}$ Yet, as Ethiopia is a civil law country highly influenced by civil law traditions, the instance of reference to foreign law and jurisprudence is likely to be rare.

Another relevant provision for purposes of interpretation is the presumption of the constitutionality of legislation. ${ }^{42}$ This implies that the onus of proving the unconstitutionality of any law or practice lies with the person or entity challenging the constitutionality of the action or omission. Finally, Article 106 of the Constitution provides that the Amharic version is authoritative.

\section{Protected Rights}

The Ethiopian Constitution incorporates several human rights. The recognition ranges from traditional civil and political rights to socio-economic and group or solidarity rights. This is further reinforced by the National Policy Principles and Objectives. The rights are generally guaranteed for everyone with some exceptions. $^{43}$

38 Consolidation of the House of Federation and Definition of its Powers and Responsibilities Proclamation No. 251/2001, Art. 7(1).

39 The Council of Constitutional Inquiry is a constitutional body established to assist the House of Federation in interpreting the Constitution. It is composed of eleven members including the President and Vice President of the Federal Supreme Court, six other legal experts with proven competence and high moral standing appointed by the President of the Republic upon recommendation of the House of Peoples' Representatives, and three others nominated by the House of Federation from among its members. See FDRE Constitution, Arts. 82-84.

${ }^{40}$ Council of Constitutional Inquiry Proclamation No.250/2001 Art. 20 (1)

${ }^{41}$ Indeed, the Council relied heavily on the US law and jurisprudence on issues of bail to reject a complaint that argued that the determination as to which crimes in relation to which bail might not be available, or available only to a limited extent may not be made by the House of Peoples' Representatives (HoPR) under the Ethiopian Constitution - see The case concerning the constitutionality of the law that excluded bail in corruption offences, Council of Constitutional Inquiry.

${ }^{42}$ See Art. 9(1) of Consolidation of the House of the Federation and Definition of its Powers and Responsibilities Proclamation No. 251/2001.

${ }^{43}$ Art. 33 (the right to nationality), Art. 38 (the right to vote and be voted for), Art 39 (the right to self-determination), Art. 40 (the right to property), and Art. 41(economic, social and cultural rights), Art. 43 (the right to development to the totality of the peoples of Ethiopia, and to nationals) all establish rights only to 


\section{1- Civil and political rights}

The Constitution embodies several civil and political rights most of which are adopted from the provisions of the UDHR. ${ }^{44}$ The list includes the right to life (which forbids deprivation of life except as punishment for a serious offence determined by law), ${ }^{45}$ to security of the person, to liberty (which prohibits arbitrary arrest and deprivation of liberty), protection against cruel, inhuman, or degrading treatment or punishment including the banning of slavery and trafficking in human beings for whatever reason, and forced or compulsory labor. ${ }^{46}$ The Constitution further guarantees the right to equality and equal protection of the law (Article 25); the right to privacy which may only be limited if "compelling circumstances" exist in accordance with law (Article 26). The freedom of religion, belief and opinion (Article 27); freedom of thought and expression including access to information of public interest; ${ }^{47}$ the right of assembly, demonstration and petition; ${ }^{48}$ the right to association for any cause or purpose (Article 31); freedom of movement including the right to reside anywhere within the national territory as well as the right to leave and return to Ethiopia (Article 32); the right to nationality, to change it at one's will, and not to lose it for the mere reason of marriage to a foreign national are also recognized. ${ }^{49}$

Individuals and groups have the right to access to justice to obtain a decision or judgment over any justiciable matter in a court of law or other competent

Ethiopians. Hence, foreigners cannot as a right claim the benefits flowing from these rights.

${ }^{44}$ In fact, the UDHR is the only human rights instrument that the Constitution expressly mentions. See art 13(2). The Constitution, though not by name, also refers to other instruments adopted by Ethiopia.

${ }^{45}$ This obviously allows the imposition of the death penalty. It does not however define what a 'serious crime' means. It is apparently left to the discretion of the legislator to determine in relation to which crimes death sentence may be imposed. For instance, the new Anti-terrorism Proclamation No 652/2009 requires the imposition of the death penalty (see Art. 3).

${ }^{46}$ See FDRE Constitution, Arts. $14-18$.

${ }^{47}$ FDRE Constitution, Art. 29. A new legislation to give effect to this provision has been enacted, see The Mass Media and Freedom of Information Proclamation No 590/2008.

${ }^{48}$ FDRE Constitution, Art. 30. A legislation has been enacted to give effect to this right, see Proclamation to Establish the Procedure for Peaceful Demonstration and Public Political Meeting No 3/1991

49 FDRE Constitution, Art. 33. An implementing legislation has been adopted. See the Ethiopian Nationality Proclamation No. 378/2003 for further detail. The constitutional provision does not however guarantee the right not to be forcefully expelled. 
body with judicial power. ${ }^{50}$ The right to vote and be elected is guaranteed to all Ethiopians of age (Article 38); similarly, the right to property is embodied under Article 40.

Moreover, the Constitution includes guarantees pertinent to the criminal justice system. The right of arrested persons ${ }^{51}$ to remain silent; to be promptly informed, in a language she/he understands, of the reasons for their arrest; to be brought before a judge in 48 hours, and habeaus corpus. It also excludes confession or admission obtained through coercion; ${ }^{.5}$ and establishes the right to bail. ${ }^{53}$ Accused persons have the right to a public trial in an ordinary court within a reasonable time; to be informed with the particulars of the charge; the privilege against self-incrimination and the presumption of innocence until proven guilty; access to and the right to challenge evidence presented against them and to adduce evidence on their behalf; the right to be represented by legal counsel of their choice; and if they cannot afford to pay for such counsel and if miscarriage of justice would result, to be provided with one at the expenses of the state ${ }^{54}$; and the right to appeal to a competent court. ${ }^{55}$

${ }^{50}$ FDRE Constitution, Art. 37. The Constitution does not provide criteria for determining, nor a definition of, justiciability of a matter. It is therefore arguable whether, for instance, the policy principles of the Constitution are justiciable. Some suggest that what is justiciable is more or less well recognized. See Fasil Nahum "A Constitution for a Nation of Nations", supra note 2 above, at 150. This, however, ignores the difference in domestic approaches on what constitutes justiciable disputes.

51 For the rights of accused persons, see FDRE Constitution, Article 20. Note that the difference between arrested and accused persons only relates to the pressing of charge. Once a charge is pressed, an arrested person becomes an accused person. Accused persons may however not always be arrested as they might exercise and be granted their right to bail.

52 Note that evidence obtained through other illegal methods, or involving procedural irregularities - such as failure to inform the arrested person of his right to remain silent, not involving coercion is not required to be discarded under the Constitution.

${ }^{53}$ See FDRE Constitution, Art19. The constitutional provision on bail is not sufficiently clear on whether the law will prescribe the general standards, to be applied by the court in each case involving individual determination, or whether the law prescribes the specific cases as to when bail may be legitimately denied (for instance depending solely on the sentence of the crime with which the suspect is charged). The Criminal Procedure Code adopts standards. See the Criminal Procedure Code of Ethiopia Proclamation No 185/1961, Arts 63(1) and 67.

54 The phrase 'miscarriage of justice' has generally been determined based on the possible punishment the charge may entail.

55 This provision may be invoked to challenge the constitutionality of the Federal Courts Establishment Proclamation No 25/1996 (Art 8(1)) which gives the Federal Supreme Court first instance jurisdiction to try criminal cases involving high government 
Persons in custody have the right to treatment that respects their human dignity. They also have the right not to be held incommunicado and hence to be visited by their spouses or partners, close relatives, friends, religious councilors, medical doctors or their legal counsel. ${ }^{56}$ The retroactive application of criminal laws is also prohibited and hence unconstitutional. ${ }^{57}$ It is however controversial whether this guarantee applies to both substantive and procedural criminal laws alike. $^{58}$ The Constitution prohibits double jeopardy in the form of re-trial or punishment for an offence upon which a final conviction or acquittal has been entered as per criminal law and procedure. ${ }^{59}$ This clearly means that double jeopardy does not apply to cases where there were irregularities in the application of the relevant criminal law or procedure.

Marital, personal and family rights with equal rights for both sexes while entering or during marriage, or at the time of divorce, ${ }^{60}$ the rights of women to

officials. Since the Supreme Court is the highest judicial body, there is no possibility of appeal from its orders or judgments. The only possible avenue is the Cassation Division of the Supreme Court which only considers questions of law, and not questions of fact which may be considered on appeal.

${ }^{56}$ FDRE Constitution, Art. 21. This provision also means that arrested persons may not be (or at least do not have the right to be) visited by others who are not listed in the provision such as foreign diplomats or the media.

${ }^{57}$ FDRE Constitution, Art. 22. This relates to criminal laws which either create a new crime, or impose more severe penalties for existing crimes. Exceptionally, retroactive application of criminal laws is permitted if it benefits the accused, for instance, by decriminalizing a previously criminal act or by reducing the penalty for such act.

${ }^{58}$ Substantive criminal law refers to those laws that create new crimes, or aggravate the punishment for existing crimes; procedural criminal law relates to other criminal laws that do not create crimes but are detrimental to the accused such as those that retroactively exclude bail. In the first case, retroactivity is prohibited. But would a law that retroactively excludes bail be unconstitutional?

${ }^{59}$ FDRE Constitution, Art. 23.

${ }^{60}$ FDRE Constitution, Art. 34. The Constitution, however, allows for the establishment of religious or customary courts such as Sharia Courts (FDRE Constitution, Art. 34(5) and 78(5)). This authorizes the adjudication of disputes of a family and personal nature in accordance of religious or customary laws, with the consent of the parties. Obviously the application of Islamic law, for instance, might lead to unequal treatment between men and women in marriage or during divorce. This obviously contradicts the equality guarantee under Arts. 25 and 34(1), and Article 35(7) which guarantees equal treatment in the inheritance of property. The House of Federation had missed a golden opportunity to rule whether decisions of customary and religious courts are appealable to regular courts when it rejected an appropriate case for want of standing - The case was submitted to the Council of Constitutional Inquiry by the Islamic Affairs Supreme Council in Tikimit 1992 (October 1999) and decided by the Council of Constitutional Inquiry on 25 January 2000. 
equality, protection from harmful customary and religious practices, right to maternity leave, right to acquire property, equal employment opportunities, and access to family planning education and information are also protected. This is further supplemented by the right to affirmative action. ${ }^{61}$ The rights of children to name and nationality, and to be free from corporal punishment or cruel and inhuman treatment in schools and other institutions responsible for the care of children is also stipulated; the best interest of the child is the primary guiding principle; juvenile offenders must be detained separately from adults; ${ }^{62}$ children born in and out of wedlock enjoy equal rights. ${ }^{63}$

\section{2- Economic, social and cultural rights (ESC Rights)}

The Ethiopian Constitution incorporates various ESC rights. Every Ethiopian has the right to freely engage in economic activities; to choose his/her means of livelihood, occupation and profession; and equal access to publicly funded services. It further requires the state to allocate ever-increasing resources to provide social services; provide funds for the rehabilitation of persons with disabilities, the aged and children without parents or guardian subject to

${ }^{61}$ FDRE Constitution, Art. 35. The Constitution (Article 7) moreover declares that provisions set out in the masculine gender also apply to the feminine gender. There is no similar counter right to family planning education and information to men. Regarding affirmative action, the Constitution does not make it clear whether and when it may stop.

${ }^{62}$ Note however that there is only one Juvenile Rehabilitation Centre situated in Addis Abeba. Hence, juveniles are in practice detained with adults in other parts of the country.

${ }^{63}$ FDRE Constitution, Art 36. The Constitution does not ban corporal punishment in a family setup. Moreover, even the principle of the best interest of the child does not expressly refer to decisions taken by the family - it only binds 'public and private welfare institutions, courts of law, administrative authorities or legislative bodies'. This interpretation is supported by the Federal Revised Family Code Proclamation No 213/2000 which authorizes courts to intervene in decisions of the parents concerning children only when the parents fail to privately settle the disagreement (Art. 266(2)). However, the Cassation Division of the Federal Supreme Court has ruled that the provisions of the Federal Revised Family Code may only be applied to the extent in compliance with the best interest of the child - see Miss Tsedale Demissie v Mr Kifle Demissie, Federal Supreme Court Cassation Division, File 23632, Judgment 6 November 2007. The principle of detention as a last resort and to the minimum possible regarding child offenders is also not guaranteed (compare Art 37(b) of the Convention on the Rights of the Child, and Rule 5 of the Beijing Rules, U.N.Doc.A/40/53/1985). We should therefore employ the interpretation provision (FDRE Constitution, Article 13(2)) to refer to international and regional human rights instruments to fill these yawning gaps in the Constitution. 
available means; ${ }^{64}$ and to pursue policies aimed at expanding job opportunities for the poor through undertaking programmes and public works projects. It also imposes a duty on the state to protect and preserve historic and cultural legacies, and to contribute to the promotion of arts and sports.

The Constitution also guarantees several labour rights. These rights include the right to association including the right to form trade unions for collective bargaining purposes; the right to strike; equal pay for equal work; paid leaves; reasonable limits to working hours; and a healthy and safe work environment. ${ }^{65}$

The ESC rights under the Ethiopian Constitution have some variation from the UDHR and ICESCR. One major difference from most civil and political rights in the Constitution is that ESC rights are guaranteed only for the benefit of Ethiopians. ${ }^{66}$ Moreover, the provisions create government obligations, rather than individual or collective rights, in a manner similar to the state policy principles and objectives. The general and duty-based formulation makes it difficult to determine whether these rights are justiciable. ${ }^{67}$ Since the Constitution does not indicate their non-justiciability, it can be argued that these rights are in fact justiciable, at least in the House of Federation. ${ }^{68}$ Justiciability will also depend on the level of activism exercised by the members of the Council of Constitutional Inquiry and the House of Federation itself. In any case, the socio-economic rights provisions of the Constitution should be

${ }^{64}$ Note that ever increasing resources does not mean maximum available resources.

${ }^{65}$ FDRE Constitution, Art. 42. Note that the Constitution does not recognize the right of employers or employers' associations to lockout. However, the Labour Proclamation No 377/ 2003 Art. 157(2) recognizes the right to lock out. This arguably raises questions of constitutionality. In any case, however, the Constitution places the right to lock out at an inferior position to the right to strike as the procedure of amendment of ordinary legislation is loose compared to the procedure of amending the Constitution.

${ }^{66}$ See FDRE Constitution, Art. 41. This is in line with Article 4 of the ICESCR which allows developing states to determine the extent to which the rights will benefit nonnationals.

${ }^{67}$ For instance, Article 41(4) provides: "The state shall have the obligation to allocate ever increasing resources to provide to the public health, and other services". This does not establish a right to health or education as such.

${ }^{68}$ In fact, since the House of Federation is itself a political body, the legitimacy question may not arise. Moreover, it seems that the justiciability argument is gradually declining (at least internationally) especially with the adoption of the Optional Protocol to the ICESCR (adopted by the UN General Assembly on10 December 2008) which recognizes complaint procedures for the rights enshrined in the ICESCR. This at least has a persuasive value in understanding the justiciability of socio-economic rights. 
formulated in a way that establishes individual justiciable rights. In this regard, the Constitution should follow the formulation employed in the ICESCR or the UDHR, in a way that creates rights than establish abstract obligations on the government.

The Constitution also guarantees several socio-economic rights as part of the National Policy Principles and Objectives. ${ }^{69}$ However, it does not expressly declare the non-justiciability of the provisions of the National Policy Principles and Objectives. ${ }^{70}$ Hence, the House of Federation or other institutions may either directly apply the principles as binding undertakings, or at least use them to guide the interpretation and understanding of the fundamental rights and freedoms. ${ }^{71}$

\section{3- Group or solidarity rights}

One essential feature of the Ethiopian Constitution is the recognition of what are called third generation or group or solidarity rights. The right to selfdetermination up to secession, the right to development and the right to a clean and healthy environment are clearly enshrined. ${ }^{72}$

The right to development is recognized as a benefit of the peoples of Ethiopia as a whole, and in the form of a right to participation. The right to clean and healthy environment similarly recognizes the right for the benefit of all persons; as such it appears more like a guarantee which accrues to each individual. The

${ }^{69}$ See FDRE Constitution, Arts. 89-91. These provisions are generally similar in formulation with Art. 41 (the ESC rights provision), except that they are more elaborate.

${ }^{70}$ The 1999 Nigerian Constitution, Section 6(6)(c) and the 1950 Indian Constitution, Section 37 unequivocally declare the non-justiciabillity of the provisions in the respective constitutions dealing with state policy principles and guidelines.

${ }^{71}$ In India, for instance, the Supreme Court has read the Directive Principles of State Policy (DPSP) into the justiciable guarantees of the Constitution despite an explicit declaration of non-justiciability. At the same time, the DPSP are employed to insulate certain measures from attack based on violation of certain justiciable rights; see for instance the case of State of Kerala v. N. M. Thomas (1976) 2 (SCC) 310 - where it was held that the fundamental rights and DPSP are complementary, 'neither part being superior to the other'. In Keshavananda Bharati v. State of Kerala (1973) 4 SCC 225 it was held that 'In building up a just social order it is sometimes imperative that the fundamental rights should be subordinated to directive principles'. See generally 'Justiciability of ESC Rights: The Indian experience' Circle of Rights Economic, Social and Cultural Rights Activism available at:

$<$ http://www1.umn.edu/humanrts/edumat/IHRIP/circle/justiciability.htm> (accessed 28 July 2010).

${ }^{72}$ See FDRE Constitution, Arts. 39, 43 and 44. 
Constitution also recognizes the right to monetary or alternative means of compensation for individuals when state programmes entail displacement or adversely affect their livelihood. ${ }^{73}$

The right of "nations, nationalities and peoples" to self-determination, up to secession ${ }^{74}$ includes the right to speak, write, develop their language; to express, promote and develop their culture; preserve their history; and to selfgovernment and equitable representation in the regional state and federal governments. The preconditions for secession are listed under Article 39: a twothirds majority support of the Legislative Council of the nation, nationality and people concerned; a simple majority vote in a referendum to be organized in a maximum of three years from the time the demand has been espoused by the relevant Legislative Council, and when transfer of power and division of assets has been effected. All this process is conducted under the auspices of the House of Federation. ${ }^{75}$

In conclusion, the Ethiopian Constitution embodies a progressive list of rights compared to its predecessors. ${ }^{76}$ The special features of the Constitution include the recognition given to the ethnic diversity and the willingness to accommodate it through the right to self-determination. However, the provisions concerning ESC rights are insufficient and there is a need to re-formulate them in tune with the ICESCR and other relevant instruments ratified by Ethiopia.

\section{4- The distinction between 'human rights' and 'democratic rights'}

The Ethiopian Constitution unduly classifies the provisions on fundamental rights and freedoms into human rights (Articles 14-28), and democratic rights

${ }^{73}$ The right to compensation only relates to state programmes. The protection does not accrue if the displacement or the adverse effect is a result of non-state programmes.

74 This, it should be noted, is a natural extension of the sovereignty conferred on nations, nationalities and peoples of Ethiopia (FDRE Constitution Art. 8(1)).

FDRE Constitution, Art. 39(5) defines a "Nation, Nationality or People" as "a group of people who have or share a large measure of common culture or similar customs, mutual intelligibility of language, belief in a common or related identities, a common psychological make-up, and who inhabit an identifiable, predominantly contiguous territory".

75 Art. 62(3) of the FDRE Constitution, and Proclamation to Consolidate the House of Federation No 251/2001 Art19.

${ }^{76}$ See, however, the discussion on the limitation and derogation of rights below. The extensive nature of permissible limitations and the list of derogable rights has significantly reduced the level of protection. 
(Articles 29-44). ${ }^{77}$ Article 10 of the Constitution creates the impression that human rights are those that emanate from the nature of mankind, and democratic rights as those inherent in democracies. ${ }^{78}$ The preparatory work of the Constitution moreover suggests that human rights are those rights that a person is entitled merely because he or she is a human being, and democratic rights are those conferred only on citizens. ${ }^{79}$ This was, for instance, how the Minster of Justice argued during a preliminary debate on the draft bill of the Ethiopian Civil Society Law. ${ }^{80}$ The Constitution clearly limits the application of a right to Ethiopians whenever it deems it necessary regarding each right. ${ }^{81}$ Moreover, limiting the application of rights to citizens will be inconsistent with international human rights instruments adopted by Ethiopia. The ICCPR for instance applies to all persons within the territory or jurisdiction of ratifying states. ${ }^{82}$ Hence, no substantive distinction should be made merely on the ground of whether a right appears under the 'human rights' or 'democratic rights' section.

${ }^{77}$ For a deeper analysis of the reasons and arguments regarding this classification, see Gedion Timothewos (2010), 'Freedom of Expression in Ethiopia: The Jurisprudential Dearth', 4(2) Mizan Law Review 207-213 arguing that the classification is 'without significant impact' and that any other interpretation of the classification will be 'absurd'. Any difference, if any, seems to be in the underlying reasons for incorporating the different category of rights rather than their practical implications i.e. human rights are recognized because they are imbued in humanity and human nature, and democratic rights are recognized because they are expressions of desirable democratic principles and governance. We should not attach practical significance to the classification especially when to do so runs against clear constitutional provisions.

${ }^{78}$ Some commentators criticize this as artificial and confusing as what are traditionally called human rights are also found in the part dealing with democratic rights. See SA Yeshaneh, "The Justiciability of Human Rights", supra note 30 above, at 275 \&276.

79 See Minutes of the Discussion on the Draft Constitution at the Council of Representatives, May 1994. See also T. Regassa "Making legal sense of human rights", supra note 3 above, at 303.

${ }^{80}$ Ethiopian Television, 5 January 2009. The Minster mentioned this in justifying the exclusion of foreign NGOs and domestic NGOs receiving more than $10 \%$ of their budget from a foreign source from engaging on issues touching upon, even tangentially, human rights and good governance.

81 Thus the right to vote and be elected, ESC Rights, right to nationality, right to property, and the right to development are clearly granted to Ethiopians. Freedom of expression and the right to association are, however, granted to the benefit of everyone though they are placed in the part dealing with democratic rights.

${ }^{82}$ Art 2(1) ICCPR. 


\section{Limitation of Rights under the Ethiopian Constitution}

Most human rights are not absolute. There may therefore be certain limits to the exercise of rights. Limitations refer to infringements or encroachments on guaranteed rights under narrowly contoured permissible circumstances. ${ }^{83}$ There are different approaches to limitation of rights in constitutions: some constitutions and international instruments include internal individualized limitation clauses within each particular right in different details; ${ }^{84}$ others have adopted general limitation clauses whose application cuts across all provisions. ${ }^{85}$ Still others adopt a combined approach because in addition to a general limitation clause they may include their own internal limitations.

The Ethiopian Constitution only contains claw-back clauses within most of the protected rights. Some of the internal limitations simply refer to those limitations determined or established by law; ${ }^{86}$ while others are more detailed and require compelling circumstances and specific laws necessary to safeguard public security, peace, the prevention of crimes, public morality, and the protection of the rights and freedoms of others. ${ }^{87}$ There are therefore different standards depending on which right the Constitution seeks to limit. The problem is exacerbated by the absence of a more sweeping general limitation clause in the Constitution that would have ensured uniformity of standards in scrutinizing the conformity of limitations of rights with the basic tenets of the Constitution.

The absence of a general limitations clause may have advantages as it leaves some rights, which do not have internal limitations, beyond limitations. For instance, the protection against torture and inhuman treatment or punishment in the Ethiopian Constitution may not in any way be limited. This will not generally be the case in a constitution that has opted for a general limitation clause. For instance, the South African Constitution allows the limitation of "the rights in the Bill of Rights" so long as it stands the constitutional test of

${ }^{83}$ They generally require legality, necessity, rational connection between the limitation and its stated purpose, and proportionality.

${ }^{84}$ For instance, the ICCPR, the Ethiopian Constitution, and the Constitution of the USA. The African Charter also does not have a general limitation clause although the African Commission on Human and Peoples' Rights has used article 27(2) as a general limitation clause - see for instance Media Rights Agenda and Others $v$ Nigeria (2000) AHRLR 200 (ACHPR 1998) Para 68.

${ }^{85}$ See for instance, the UDHR Art. 29(2), and the Constitution of the Republic of South African, section 36(1).

${ }^{86}$ For instance, the right to life, liberty, bail, (FDRE Constitution Arts. 15, 17 and 19 respectively).

${ }^{87}$ The rights to privacy, freedom of religion, belief and opinion, freedom of expression and assembly and association (FDRE Constitution, Arts. 26, 27,29, 30, 31). 
reasonability and justifiability. ${ }^{88}$ Hence, in the absence of a general limitation clause, it is possible to have a right that may not be limited in any way, if there is no internal limitation to that effect. However, lack of a general limitation clause can have its downsides, as it might invite arbitrary, limitless limitations. Some in fact describe the general limitation clause as the most important clause in a bill of rights. ${ }^{89}$ If there is a general limitation clause, however, every right is potentially limitable and rights with internal limitation will be subjected to double limitation analysis. ${ }^{90}$

Several problems can be identified concerning the possible limitation of rights in the Ethiopian Constitution. First, there is no requirement in some cases, such as the right to life and liberty, that the limitation be rationally connected to the purpose it aspires to achieve, and be necessary and proportional so long as the limitation is based on law. ${ }^{91}$ The provisions only adopt the legality requirement implying the acceptability of limitations so long as such limitations are established or determined by law without any inquiry into the fairness and propriety of the law. The minimum threshold for restraining fundamental rights and freedoms is significantly low. For instance, it is not clear whether a law that imposes capital punishment on children will stand the

${ }^{88}$ See section 36 of the Constitution of the Republic of South Africa. The Constitutional Court of South Africa has for instance held that even the rights of children are subject to the limitation analysis - see the case of S v M 2008 (3) SA 232 (CC) Para 18.

89 Stuart Woolman (1994), "Riding the push-me pull-you: Constructing a test that reconciles the conflicting interests which animate the limitation clause", 10 South African Journal on Human Rights 60, at 60.

90 For instance, most of the socio-economic guarantees in the South African Constitution are internally limited to the availability of resources. They are moreover subject to possible limitation under Section 36 of the same Constitution - See for instance Sections 26(right to housing) and 27 (the right to health and social security).

${ }^{91}$ For the principles that should guide limitation and derogation of rights, see the Siracusa (1985), "Principles on the Limitation and Derogation of Provisions in the International Covenant on Civil and Political Rights", UN Economic and Social Council, U.N. Sub-Commission on Prevention of Discrimination and Protection of Minorities, Annex, UN Doc E/CN.4/1985/4. According to these principles, limitation of rights must be based on (1) law, (2) have a legitimate aim, and (3) be necessary.

The Indian Supreme Court during its initial stages accepted all limitations so long as established by law without any inquiry into its fairness. It for instance allowed preventive detention so long as provided by law - A.K. Gopalan v. State of Madras, AIR 1950 SC 27. This understanding was later rightly reversed in favour of the requirements of guarantees of non-arbitrariness, reasonableness and fairness implicit in the provisions that protect human rights in Maneka Gandhi v. Union of India, AIR 1978 SC 597. 
test of constitutionality. ${ }^{92}$ Apparently, so long as the limitation emanates from a law, whatever its purpose, it is a permissible limitation. There is moreover no definition as to what 'law' means: does it include parliamentary statutes only? Or does it also include regulations, directives or even rules and practices of administrative agencies? Should it moreover be a law of general application, clear, precise and accessible allowing predictability $?^{93}$

These are pertinent questions that need to be answered before limitations on the protected rights. In determining the justifiability of limitations, reference should be made to international and regional instruments and the jurisprudence of established treaty forums. The UDHR, for instance, includes a general limitation clause under Article 29. This should guide the determination of the justifiability of limitations on those rights that have internal limitations. It should, however, not be used to justify the limitation of rights whose limitation has not been anticipated by the Constitution i.e. provisions which do not incorporate internal limitations.

\section{Derogation in Cases of Emergencies}

The Ethiopian Constitution recognizes possibilities that may require the suspension of protected rights. ${ }^{94}$ Derogation clauses relate to provisions that

92 There is a provision in the Ethiopian Criminal Code (Proclamation No 414/2004) which prohibits the imposition of the death penalty on persons under the age of eighteens at the time of the commission of the crime (Art 117(1)). But this is only a guarantee by an ordinary legislation which may be reversed through an amendment or modification in an ordinary procedure. It is to be noted that new anti-terrorism proclamation, for example, imposes death penalty and does not embody an express exception to infants and young offenders. Yet, Articles 52 to 56 of the 2004 Criminal Code and other provisions such as Art. 117(1) of the same Code are applicable as the General Part of the Criminal Code applies to all special criminal legislation by virtue of Art. 3 of the Criminal Code. See also Article 36 of the Constitution which guarantees the right to life of the child.

${ }^{93}$ See for instance the European Court of Human Rights in the case of Klass \& Others c. Allemagne v. Germany (1979) 2 EHRR 214, which defined law broadly, and Sunday Times $v$ United Kingdom (1979) 2 EHRR 245, where it was held that the law must be clear and accessible with foreseeable consequences.

${ }^{94}$ FDRE Constitution, Art. 93. Derogations are different form limitations in that they are often temporary and may suspend a right wholly. Limitations on the other hand may be permanent and are meant to perpetually balance the public interest with the rights of individuals and groups; unlike derogations, limitations cannot negate the essential element of a right. Moreover, there is no need for emergencies to justify limitation of rights; but emergencies or crises are condition precedents for the legitimate derogation from or suspension of rights. 
permit the temporary suspension of the application and enjoyment of rights in response to incidences of emergency that threaten the life of a nation. ${ }^{95}$ Derogations do not, however, confer absolute discretion on the executive to act on its whims; there are substantive as well as procedural requirements that govern such emergency situations. ${ }^{96}$ There are, moreover, certain rights, which may not be suspended even in threatening situations. These preconditions are designed as a protection against possible abuses of human rights on the pretext of emergencies while at the same time authorizing states to secure, maintain and ensure the sustenance of fundamental national and international interests.

Article 93 of the Constitution prescribes the requirements, both procedural and substantive. The only conditions that may justify derogations are occurrence of an external invasion, a breakdown of law and order which cannot be controlled by the regular law enforcement agencies and personnel, or the occurrence of a natural disaster or an epidemic.

The Council of Ministers of the federal Ethiopian government has the power to declare state of emergency under any of the above situations. The Regional States are also allowed to declare state of emergency to avert natural disaster or epidemic within their respective territories. The ultimate power to approve or annul a declaration of emergency made by the Council of Ministers, however, lies with the House of Peoples' Representatives (HoPR). This decision is required to be made within 48 hours if the HoPR is in session, or within 15 days

95 See the Siracusa Principles and the Paris Minimum Standards of Human Rights Norms (International Law Association, 1985); RB Lillich (1985), "The Paris Minimum Standards of Human Rights Norms in a state of emergency", 79 American Journal of International Law 1072, at 1075.

96 F.N. Aolain (1995), "The emergence of diversity: Differences in human rights jurisprudence" 19 Fordham International Law Journal 101, at 101.

The African Charter on Human and Peoples' Rights does not contain any derogation clause. The African Commission on Human and Peoples' Rights has interpreted this omission as prohibition of derogation from the Charter provisions. See for instance, the case of Commission Nationale des Droits de l'Homme et des Libertes $v$ Chad (2000) AHRLR 66 (ACHPR 1995) Para 21; Media Rights Agenda and Others $v$ Nigeria (2000) AHRLR 200(ACHPR 1998) Para 67 - implying that all the rights in the African Charter are essentially non-derogable. Some however argue that this should not be the case - see F Ouguergouz (2003), The African Charter on Human and Peoples' Rights: A comprehensive agenda for human dignity and sustainable democracy in Africa (Brill Academic Publishers); C Heyns "Civil and Political Rights in the African Charter" in M Evans \& R Murray (eds) The African Charter on Human and Peoples' Rights the system in practice 1986-2000 (2002, Cambridge University Press) at 139. 
if the HoPR is not in session at the time of the declaration of emergency. ${ }^{97}$ Upon approval by a two-third majority vote, the state of emergency may remain up to six months subject to its renewal for up to four months on each occasion through the same procedure. ${ }^{98}$ If annulled, the declaration will be repealed forthwith. ${ }^{99}$

The Constitution authorizes the possible suspension of most of the fundamental human rights and freedoms to "the extent necessary" with handful exceptions. ${ }^{100}$ The only non-derogable rights are the prohibition against cruel, inhuman, and degrading treatment or punishment, and slavery or servitude, and trafficking (Article 18), the right to equality and equal protection of the law (Article 25), and the right to self-determination up to secession (Article 39). ${ }^{101}$

The Constitution requires the HoPR to establish, simultaneously with the approval of the state of emergency, an ad hoc State of Emergency Inquiry Board consisting of seven members chosen and assigned by the House from among its members and from legal experts. ${ }^{102}$ This body, among others, monitors and follows up the situation to ensure that no measure taken during the state of

${ }^{97}$ It should be noted that the HoPR only has the final say over federal declarations of emergency by the Council of Ministers. States have their own constitutional provisions governing emergency declarations and there is no need for approval by the HoPR.

${ }^{98}$ The review power of the House of Peoples' Representatives (HoPR) is in line with the Paris Minimum Principles which require judicial or other review mechanisms. Note that the Constitution does not set a maximum period for the state of emergency; it may therefore last indefinitely so long as it gets approved by the HoPR.

99 This implies that the annulment has only prospective effect. This is particularly worrisome in cases where the HoPR is not in session, but annuls the declaration of emergency later, as damage may already have been done within the 15 days. Hence, the procedure might leave victims without remedy.

100 This is a significant internal limitation that exacts necessity and proportionality which relates to the severity, duration and scope (geographical) of the application of the emergency declaration. For more discussion on requirements of necessity and proportionality see Aly Mokhtar (2004) 'Human rights obligations vs Derogations: Article 15 of the European Convention on Human Rights' 8(1) International Journal of Human Rights 68; see also the case of Lawless v. Ireland (Merits) § 28, European Court of Human Rights, 1961, Ser. A.

${ }^{101}$ The other provision which is non-derogable is the Federal and Democratic structure of the state. See FDRE Constitution, Article 93(4) (b \&c). The constitutional list of non-derogable rights clearly differs with the list of non-derogable rights in the ICCPR (Article 4) - the right to life and the prohibition of retroactive application of criminal law are for instance missing in the constitutional list.

102 See FDRE Constitution, Art 93(5). The proportion between the number of members of the House and legal experts is left to the discretion of the HoPR - there is no minimum requirement. 
emergency is inhuman and ensures the "prosecution of perpetrators of inhuman acts".

It is worth noting that the Constitution does not provide for the duty of the Council of Ministers or the HoPR to publish the State of Emergency declaration and ensure its accessibility. Moreover, it does not reaffirm the duty of the State to inform, inter alia, member states to the ICCPR. ${ }^{103}$

\section{Amending the Fundamental Rights and Freedoms Provisions}

Amendment is a mechanism by which constitutions adapt to changing circumstances through "perfecting imperfections". ${ }^{104}$ Constitutional amendment procedures should set the balance between the inherent need to adapt and ensure stability, and the necessity to bar regressive gold-digging alterations.

The Ethiopian Constitution adopts two distinct procedures of amendment: one relating to the fundamental rights and freedoms provisions, and another for the rest of the Constitution. ${ }^{105}$ The procedure for amending the bill of rights is more stringent. ${ }^{106}$ This is a further manifestation of the commitment of the Constitution's preamble to fully respect and protect fundamental rights and freedoms as a pillar and precondition of an ordered and democratic society.

As a federal state, the Constitution represents, protects and preserves the mutual interest of the federal government as well as the regional states. Any amendment procedure should, therefore, accommodate the interest of both entities. Amendments to the human rights provisions of the Constitution may only be approved when all the Regional State Councils approve the proposed amendment; and when the HoPR and the House of Federation, in separate sessions, approve the proposed amendment by a two-third majority vote. Other provisions of the Constitution may be amended if: the HoPR and the House of

${ }^{103}$ Art 4 of the ICCPR requires states to inform other member states when declaring emergencies.

104 See J Hatchard (1998) "Perfecting imperfections': Developing procedures for amending constitutions in commonwealth Africa" 36(3) The Journal of Modern African Studies 381.

${ }^{105}$ FDRE Constitution, Art. 105. Note that these procedures are different from the way ordinary legislation is adopted and amended which is by a simple majority vote in the HPR. The State Councils are not in any way involved in the adoption and amendment of federal (ordinary) laws.

106 Note however that under the current political realities, these procedural safeguards are irrelevant as the ruling Ethiopian People's Revolutionary Democratic Front (EPRDF) currently controls more than $99 \%$ of the federal parliamentary seats. There has been a similar trend of dominance since the first Ethiopian multi party elections in May 1995. 
Federation in a joint session approve the amendment by a two-third majority vote, and when two-third of the State Councils approves the proposed amendment by majority vote.

Apparently, the de jure procedure of amending the human rights provisions of the Constitution is stringent enough to discourage retrogressive amendments. It is, however, at the same time so rigorous as to exclude any upgrading of the constitutional protection of rights. Hence, constitutionalization of new rights ${ }^{107}$ as well as amendments to raise the level of protection of recognized rights ${ }^{108}$ would have to pass through the same exclusionary procedure intended to preclude retrogressive amendments. Hence, the Constitution could have adopted two separate amendment provisions apropos its human rights provisions depending on the consequences of the amendment on the level of protection of the fundamental human rights and freedoms. Less stringent procedures for progressive amendments that aim at increasing the list of rights or the scope of guaranteed rights could have been preferable. ${ }^{109}$

Moreover, the Constitution does not anticipate the possibility of holding a referendum to amend the Constitution. This is the case even when there is a stalemate between the major actors. For instance, the HoPR, or the House of Federation, or the State Councils, or even the Council of Ministers may support an amendment, yet one of the others may be against it. In such cases, direct vote of the public on the amendment should have been called for ${ }^{110}$ However, there is no procedure that requires the participation of the public at large in approving certain sensitive amendment proposals. ${ }^{111}$ Moreover, there is no room in the amendment procedure for representatives of civil society and other relevant actors. The Constitution does not also anticipate provisions that may not be amended under any circumstances. Most importantly, since the more stringent procedure applies to amending those provisions in Chapter 3, other provisions

${ }^{107}$ For instance, there is no right to remedy for violations of human rights in the Constitution. There is also no prohibition of arrest for failure to pay a civil debt. Moreover, all the socio-economic rights are not really couched as rights, rather as goals.

${ }^{108}$ For instance, to amend the right to life provision to abolish the death penalty.

109 The author is aware that such a provision may be abused. However, whenever there are differences on the possible consequences of a proposed amendment, the dispute may be subject to judicial resolution, or to resolution by the House of Federation as it is the organ responsible for the interpretation of the Constitution.

110 For instance, in the 1990 Constitution of the Republic of Benin, referendum is necessary when a proposal fails to secure $4 / 5^{\text {th }}$ of the votes of the National Assembly. See Arts. 154-56.

${ }^{111}$ For more on the merits and demerits of holding referendum to amend Constitutions see Hatchard 'Perfecting imperfections", supra note 104 above. 
relevant to human rights but that are found outside this Chapter, such as the provision dealing with derogation in emergency situations, may be amended through the ordinary procedure.

\section{Adjudication of Constitutional Disputes}

All judicial power rests with an independent judiciary and courts which are subject only to the law. ${ }^{112}$ The Ethiopian Constitution establishes two parallel judicial structures: one at the Federal level, which hierarchically consists of the First Instance Court, High Court and the Federal Supreme Court, and one at the State (Regional) level consisting of First Instance (Woreda) Courts, High (Zonal) Courts, and Regional Supreme Courts. ${ }^{113}$

However, as mentioned earlier, the power of interpreting the Constitution lies with the House of Federation consisting of representatives of nations, nationalities and peoples. ${ }^{114}$ Apparently, the Constitution either does not consider the role of the judiciary in the adjudication of constitutional disputes, or it has made an exception to the judicial power of courts. With regard to the legal expertise required in constitutional interpretation, the Constitution establishes the Council of Constitutional Inquiry, mainly composed of legal experts, to assist the House of Federation in determining whether there is need for constitutional interpretation, and if so, to provide recommendations to the HoF for a final decision. ${ }^{115}$

${ }^{112}$ FDRE Constitution, Arts. 78 and 79.

${ }^{113}$ Note also that the Constitution authorizes the adjudication of personal and family disputes in accordance with customary and religious laws upon the consent of both parties (Article 34(5)). Consequently, Sharia Courts have been established all over the country.

${ }^{114}$ See FDRE Constitution, Art. 62(1). This is atypical of most other systems where such power is often vested in either ordinary courts or a special court established solely for such purpose. For a discussion on whether this approach represents a response to the counter-majoritarian dilemma and the legitimacy of the approach see YT Fisseha (2004) "Who interprets the Constitution: A descriptive and normative discourse on the Ethiopian approach to constitutional review" LLM Dissertation (Faculty of Law, University of Pretoria). For a discussion of the most common type of institutions engaged in judicial review of constitutions in most countries, see WK Geck 'Judicial review of statutes: A comparative survey of present institutions and practices' (1965-1966) 51 Cornell Law Quarterly 250

115 FDRE Constitution, Arts. 62(2), and $82-84$. The Council has 11 members consisting of both legal experts and politicians: the President and Vice President of the Federal Supreme Court, six legal experts appointed by the President of the Republic upon recommendation by the House of Peoples' Representatives, and three persons appointed by the House of Federation from among its members. 
The Constitution requires that 'all constitutional disputes' shall be decided by the HoF. ${ }^{116}$ The jurisdiction of the HoF extends to contentions over the constitutionality of Federal or State laws. ${ }^{117}$ Despite the clear constitutional provision empowering the $\mathrm{HoF}$ and the Council of Constitutional Inquiry to preside over constitutional issues, there has been an academic debate on whether there is anything left for courts to interpret the Constitution.

A. Fiseha argues that it is only the constitutionality of legislative enactments that is exclusively reserved to the House of Federation and the Council as implied in Art. 84(2) which only refers to 'any federal or state law'. ${ }^{118}$ The Amharic version particularly makes it even clearer as it refers to laws made by legislative organs. Similarly, Donovan argues that the drafters of the Constitution only had the intention to take away from the ordinary courts the power to invalidate statutes as unconstitutional. ${ }^{119}$ He reinforces his arguments with the constitutional duty of courts to enforce the Constitution as every small measure of enforcement unavoidably involves some kind of interpretation. ${ }^{120} \mathrm{I}$. Idris moreover notes that 'any petition on the unconstitutionality of an administrative act or a decision or custom is within the judicial jurisdiction of an ordinary court'. ${ }^{121}$ In short, they argue that the Courts have the residual power to consider constitutionality of cases that, for instance, involve violation of rights by the executive. ${ }^{122} \mathrm{~T}$. Regassa moreover states that judicial review is a normal

${ }^{116}$ Article 83(1).

117 See FDRE Constitution, Art. 84(2).

118 See A. Fiseha (2001), 'Constitutional Interpretation: The Respective Role of the Courts and the House of Federation', in Proceedings of the Symposium on the Role of Courts in the Enforcement of the Constitution (Addis Ababa) pp. 6-26; A Fiseha (2005) 'Federalism and the Adjudication of Constitutional Issues: The Ethiopian Experience', Netherlands International Law Review 1; see also I Ibrahim (2002), 'Constitutional adjudication under the 1994 FDRE Constitution' 1(1) Ethiopian Law Review 62; T. Regassa (2000) 'Courts and the human rights norms in Ethiopia' in A. Fiseha (eds) Proceedings of the symposium on the role of the courts in the enforcement of the Constitution, (Ethiopian Civil Service College).

${ }^{119}$ DA Donovan (2002) 'Leveling the Playing field: the Judicial duty to protect and enforce the constitutional rights of accused persons unrepresented by counsel', 1 Ethiopian Law Review 31.

${ }^{120}$ Articles 9(2) and 13(1) FDRE Constitution.

${ }^{121}$ I. Idris (2002), 'Constitutional adjudication under the 1994 FDRE (Federal Democratic Republic of Ethiopia) Constitution' 1Ethiopian Law Review 6371

${ }^{122}$ A. Fiseha (2005), 'Federalism and the Adjudication of Constitutional Issues: The Ethiopian Experience' Netherlands International Law Review 1, 21 
inherent business of courts as is implied, in the Ethiopian case, in the vesting of all judicial power in the courts. ${ }^{123}$

'Law' has been defined very broadly to include proclamations issued by the Federal or State legislative organs, and regulations and directives issued by the Federal and States government institutions and also international agreements. ${ }^{124}$ Some scholars consider this expansive interpretation as a 'blunder' and unconstitutional encroachment upon the implied residual jurisdiction of ordinary courts under the Constitution to consider the constitutionality, for instance, of directives, regulations, executive action as well as international agreements. ${ }^{125}$

The scholars who argue that Ethiopian courts have the power to look into the constitutionality of all acts and omissions except that of legislative statutes seem to rely exclusively on Article 84(2) which appears to only refer to legislative enactments ignoring Article 83(1) which simply says 'all constitutional disputes' shall be decided by the House of Federation. All constitutional disputes necessarily include any constitutional issue, whether or not it involves interpretation or application of the Constitution. Besides, it is Article 83 that determines the substantive issue on which organ has the power to interpret the Constitution. Article 84 only outlines the power relationships between the Council and the House of Federation and the procedure that should be followed to address constitutional issues.

The argument that courts have a residual power to adjudicate over constitutional issues not involving the constitutionality of legislative acts seems

${ }^{123}$ Article 79(1). See T. Regassa, "Courts and the Human Rights Norms in Ethiopia" in F A. Fiseha (ed) Proceedings of the symposium on the role of the courts in the enforcement of the Constitution (2000) 116. The argument which should be noted is what led the US Supreme Court to assume the power of judicial review in Marbury $v$ Madison although the US Constitution did not explicitly grant such power.

124 Art 2(2) of Proclamation No 251/2001. Note that there is a difference in the definition of the scope of 'law' in this Proclamation and the Council of Constitutional Inquiry Proclamation No 250/2001 which does not include directives of State or Federal institutions (see art 2(5) of Proclamation No 250/2001).

${ }^{125}$ See for instance A Fiseha (2005), 'Federalism and the Adjudication of Constitutional Issues: The Ethiopian Experience' Netherlands International Law Review 1, 20; see also I Ibrahim (2002), 'Constitutional adjudication under the 1994 FDRE Constitution' 1(1) Ethiopian Law Review 62; R Tsegaye (2000) 'Courts and the human rights norms in Ethiopia' in A Fiseha (ed) Proceedings of the symposium on the role of the courts in the enforcement of the Constitution, Ethiopian Civil Service College); A Fiseha (2000) 'Constitutional interpretation: The respective role of courts and the House of Federation' in A Fiseha (ed) Proceedings of the symposium on the role of the courts in the enforcement of the Constitution (Ethiopian Civil Service College); 
to be based on a selective reading of the provisions of the Constitution. ${ }^{126}$ Even if we assume that there is actually a residual power, Fisseha convincingly argues that judicial review for constitutionality may not be understood as an inherently judicial power particularly in Ethiopia where historically 'declaring a law void for its repugnancy to the constitution has never been considered as the normal business of the courts'. ${ }^{127}$ M. Haile also observed that the absence of a clear provision granting residual power to courts only creates a lacuna and does not necessarily imply that courts will arrogate that residual power, if any, to themselves. $^{128}$

In Ethiopia, the power to pass final decision over all constitutional disputes lies with the House of Federation and the role of courts is utterly limited to referring cases to the Council of Constitutional Inquiry wherever a case may not be resolved without first determining the constitutionality of the law based on which it is to be decided. ${ }^{129}$ There should not be confusion between what ought to be (i.e., courts should have some power in interpreting the Constitution) visà-vis what is the law as it currently exists (i.e., the power of constitutional review lies with the HoF and Council of Constitutional Inquiry). Since the House of Federation is a political organ, and judicial review inherently requires the involvement of the judiciary, it is hard to say that there exists judicial review in Ethiopia. ${ }^{130}$ This is true to legislative acts, administrative acts or omissions or custom so long as the issue of their contradiction with the Constitution arises. ${ }^{131}$ This has created a judiciary with a very limited role in the formulation, content

${ }^{126}$ This does not however mean that courts do not have any role in the enforcement of the Constitution. There are several means through which courts can play a role such as through interpreting domestic legislation in line with the Constitution or a precedent set by the House of Federation.

${ }^{127}$ Y. Fisseha, supra note 114, p. 16. Fisseha further indicates that constitutional review is not the role of courts in for instance France, England, New Zealand and several other countries.

${ }^{128} \mathrm{M}$ Haile 'The new Ethiopian Constitution: Its impact upon unity, human rights and development' (1996-1997) 20 Suffolk Transnational Law Review 155

${ }^{129} \mathrm{Ibid}$, at 54, noting that 'ordinary courts have no jurisdiction to constitutional issues.

${ }^{130}$ Haile similarly notes that the House of Federation is not a judicial body - Haile " (supra note 128) 54

131 This means that if the issue is the contravention of administrative acts or custom with general principles of administrative law or a proclamation, then it is for the courts to determine whether there is such contravention. This is an administrative judicial review which should be distinguished from constitutional judicial review which essentially depends on the standard against which the constitutionality of any act or omission is to be tested. 
and implementation of state policies in Ethiopia. ${ }^{132}$ Since the HoF is itself a political body, all the human rights, including socio-economic rights, provisions should be justiciable and the relevance of the 'political question' doctrine as developed by the US Supreme Court seems less relevant. ${ }^{133}$

\section{Constitutional Remedies}

The Ethiopian Constitution does not have a provision that deals with remedies that may come out of constitutional dispute resolutions. However, Article 37(1) entitles everyone to access courts or other competent bodies to obtain a decision or judgment concerning any 'justiciable matter'. ${ }^{134}$ The orders and remedies will therefore have to be determined by the House of Federation in each case. Quite surprisingly, there is no explicit duty on the HoF to declare the invalidity of a law or practice inconsistent with the Constitution although the Constitution deprives effect to any law, customary practice or a decision of an organ of state or public official in contravention of it. ${ }^{135}$

The legislation enacted to define the powers of the House, however, has some relevant provisions on the effect of its decisions. Any decision and remedy applies only prospectively unless otherwise indicated in the decision. ${ }^{136}$ This is

132 This does not mean that courts have no role in enforcing human rights. Courts can, for instance, ensure compliance with human rights that have been declared in proclamations, and can ensure the conformity of regulations and directives with the enabling proclamations. Courts can also exercise a significant role in interpreting the Constitution while determining whether to refer a constitutional issue to the Council of Constitutional Inquiry or the House of Federation. Such referral power presents for courts the opportunity to undertake preliminary constitutional interpretation. See AK Abebe (2010) 'Towards more liberal standing rules to enforce constitutional rights in Ethiopia' 10(2) African Human Rights Law Journal 401 at 419-420. See also Takele Soboka Bulto 'Judicial referral of constitutional disputes in Ethiopia: From practice to theory' (2011), 19 African Journal of International and Comparative Law 99.

${ }^{133}$ For a discussion of the political question doctrine, see P Daly (2010) "Justiciability and the 'political question' doctrine" Public Law 160.

${ }^{134}$ As indicated earlier, there is no clear definition of a 'justiciable matter'. The South African Constitution is very conspicuous in this regard as it grants access to courts in relation to 'any dispute that can be resolved by the application of law'. See section 34.

${ }^{135}$ FDRE Constitution, Article 9(1).

136 Proclamation No 251/2001, Art 16(1). Compare the South Africa Constitution Section 172(1)(b)(i) which authorizes courts to limit the retrospective effect of the declaration of invalidity (without such limitation, the order will have retrospective application). - See for instance the case of Occupiers of Olivia Road v City of 
apparently incompatible with Article 9 of the Constitution, which denies effect to inconsistent acts or omissions from the beginning (void ab initio), which necessitates a retrospective application of remedies. ${ }^{137}$

The legislation also authorizes the House to grant a grace period of up to six months to the Federal or the State legislative body to amend or repeal the law in question before a final decision on its unconstitutionality is taken. ${ }^{138}$ This is a novel approach that gives the HoF a rather mediatory role between disputants. There is, however, no provision authorizing the suspension of a decision of invalidity made by the HoF if it opts to do so for different reasons. ${ }^{139}$ This would have been used, for instance, to avoid legal gaps in the interim between declaration of invalidity and adoption of a new or amended legislation through giving the legislative body the chance to address the inconsistency that resulted in the declaration of invalidity. It is moreover not apparent if the HoF may grant any other remedy, such as compensation, than declaring the unconstitutionality of the defective act or omission. ${ }^{140}$

The interpretation of the HoF generally applies on similar constitutional matters that may arise in the future. ${ }^{141}$ Although the decisions of the HoF are non-appealable, this should not be understood to preclude the HoF from changing or modifying its previous interpretations. The legislation also introduces the principle of severability which limits the effect of declaration of invalidity to parts of a given law which are inconsistent unless otherwise necessary to completely invalidate the whole law. ${ }^{142}$ Hence, if the rest of the law can be given effect without the flawed provision, the law remains valid.

Johannesburg et al Case CCT 24/07[2008] ZACC 1 Para 52 where the Constitutional Court excluded retroactive application of its orders.

${ }^{137}$ Note that the Constitution says 'shall be of no effect' implying that the inconsistent act or omission is void ab initio. This requires that parties should be reinstated (by applying the remedies retrospectively) to their position prior to the violation to the extent possible.

${ }^{138}$ Proclamation No 251/2001, art 16(2).

${ }^{139}$ The South African Constitutional Court does not have a mediatory role per se. But it has the right to suspend its declaration of invalidity whenever considered just and equitable - see section 172(1)(b)(ii).

${ }^{140}$ This seems to be unlikely as the mere role of the House of Federation or the Council of Constitutional Inquiry is to ascertain whether the act or omission challenged is Constitutional. It is essentially an abstract review that does not require a concrete case.

${ }^{141}$ Proclamation No 251/2001, Art. 11(1).

${ }^{142}$ Proclamation No 251/2001, Article 12 . The South Africa Constitution similarly says 'invalid to the extent of its inconsistency' (Section 172(1)(a)). 


\section{Conclusion}

In conclusion, the Ethiopian Constitution contains a fairly long list of rights of all categories; hence, the main problem in Ethiopia does not seem to be lack of human rights guarantees. The interpretation provision of the Ethiopian Constitution should apply not only to the provisions in Chapter 3 but also in relation to all other provisions relevant to human rights particularly the applicability of the derogation provision. The mode of formulation of the socioeconomic rights provisions of the Constitution is, however, problematic. There is therefore the need to amend it in the line with the ICESCR. There is also the need to clearly provide for possible remedies in the proclamations that regulate the powers of the Council of Constitutional Inquiry and the House of Federation. Moreover, there is no formal recognition of the judicial enforcement of the human rights provisions of the Constitution. Despite various scholarly works suggesting otherwise, the Ethiopian Constitution has kept courts at arm's length from constitutional interpretation. This has diminished the role of Ethiopian courts as the ultimate custodians of human rights protected under the Constitution and other laws.

In light of international and regional human rights instruments that can be used as guides, the House of Federation, the Council of Constitutional Inquiry, courts, the Ethiopian Human Rights Commission and other organs which may be involved in constitutional interpretation can indeed explore good practices from the experience and rich jurisprudence of international, regional and foreign jurisdictions in the area of human rights. Meanwhile, any limitation that may be imposed on the rights recognized in the Ethiopian Constitution should only be accepted when it is justifiable and necessary in accordance with a law (that is clear and accessible), and with due regard to the implications for its proportionality in a democratic society. 